補緅誌, J Jpn Prosthodont Soc, $31:$ 1445 1453, 1987.

\title{
磁性合金の補綴領域における応用
}

第 5 報＼cjkstart磁性アタッチメントとその骨植不良歯への応用

石幡 伸雄 水谷紘 藍稔

\section{Application of Ferromagnetic Alloy for Prosthodontics}

Part 5. Application of Magnetic Attachment for Prosthetically Hopeless Teeth

Nobuo Ishihata, Hiroshi Mizutani and Minoru Ai

\begin{abstract}
Previous studies have shown that $\mathrm{SmCo}_{5}$ magnets can be used for overdenture retainer and that 3 different types of magnetic attachments are developed. One of the most significant merits of these magnetic attachments is that they can be available for prosthetically hopeless teeth-teeth with bone loss or large mobility. We have successfully used these magnetic attachments in more than 35 hopeless teeth for periods of up to 7 years. Here we introduce 3 typical cases among them. Radiographs of abutment teeth applied with magnetic attachments show alveolar bone improvement and this is to clear the usefullness of magnetic attachment.
\end{abstract}

Key words : samarium-cobalt magnetic attachment, overdenture retainer, prosthetically hopeless teeth

\section{I. 緒 言}

著者らはこれまでサマリウムコバルト合 金 $\left(\mathrm{SmCo}_{5}\right)$ 磁石を磁性アタッチメントとして臨床に応用する方法を 検索してきた ${ }^{1 \sim 4)}$. 第 1〜第 3 報では, $\mathrm{SmCo}_{5}$ 磁石を臨床 応用するうえでの種々の問題点を解決する方法や, 維持 力となる吸引力の増強方法に関する基礎的実験について 報告し，第 4 報ではこれらの実験結果をふまえて製作し た磁性アタッチメントの臨床応用例を示した.

一方, これらの磁性アタッチメントを部分床義歯の維 持装置として，骨植不良歯 25 例使用して経過観 察し てきたが，良好な結果を得ることができた．そこで今回 その一部を報告する.

東京医科歯科大学齿学部第 1 歯科補緅学教室

First Department of Prosthodontics, Faculty of Dentistry, Tokyo Medical and Dental University

昭和 62 年 6 月 25 日受付

\section{II. 磁性アタッチメントの種類}

著者らが使用した磁性アタッチメントは, 製作法の違 いやその構造的な特徴によりつぎの 3 種類に 分けられ る.

1）磁性アタッチメントI 型 (図 1-a, 図 2-a)

これは根面板部および磁石を内包する上部構造（ヨー ク）から成り，いずれも磁性合金 $\mathrm{E}^{1)}$ で鋳造製作されて いる. ークの内部には $3 \phi \times 2 \mathrm{~mm}$ または $4 \phi \times 1.5 \mathrm{~mm}$ の円柱形磁石が 1,2 個捜入され, 根面板部上面にはヨ 一クの横摇れ防止のための突起が付与されている. 吸引 力は $180 \sim 280 \mathrm{~g}$ である.

2）磁性アタッチメントII型（図 1-b，図 2-b)

ヨークは既製でステンレスあるいは磁性合金 Eで製作 されている. 使用磁石は $3 \phi \times 2 \mathrm{~mm}$ または $4 \phi \times 1.5 \mathrm{~mm}$ で，根面板部は既製のステンレス円板を合釷部分と歯科 用鋳造合金で鋳接するか, 磁性合金 Eで全体を鋳造して 製作する. 吸引力は $250 \sim 400 \mathrm{~g}$ である. 


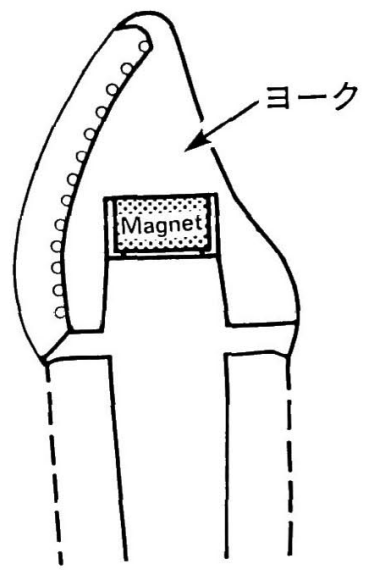

a. I 型

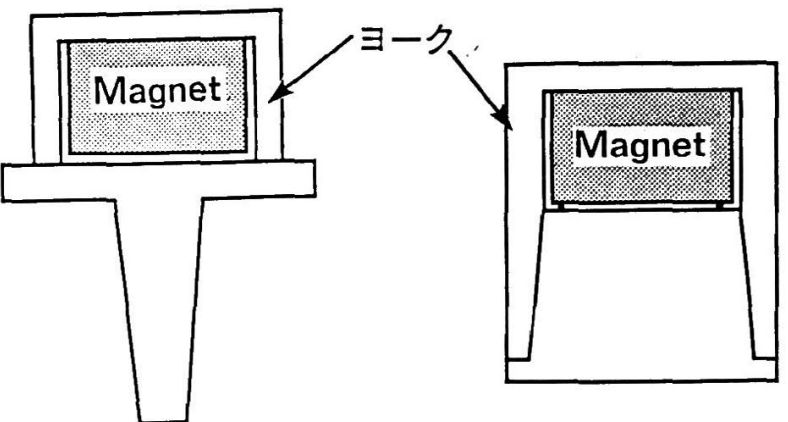

b. II 型 c. 皿型

図 1 磁性アタッチメント模式図

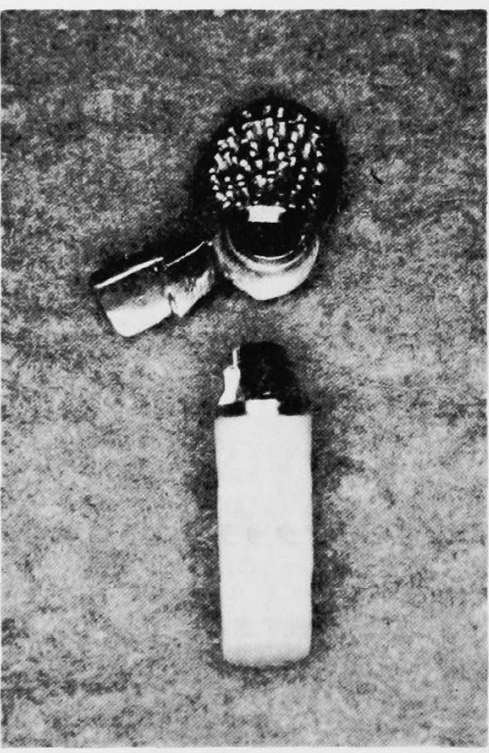

a. I 型

図 2 磁性アタッチメント

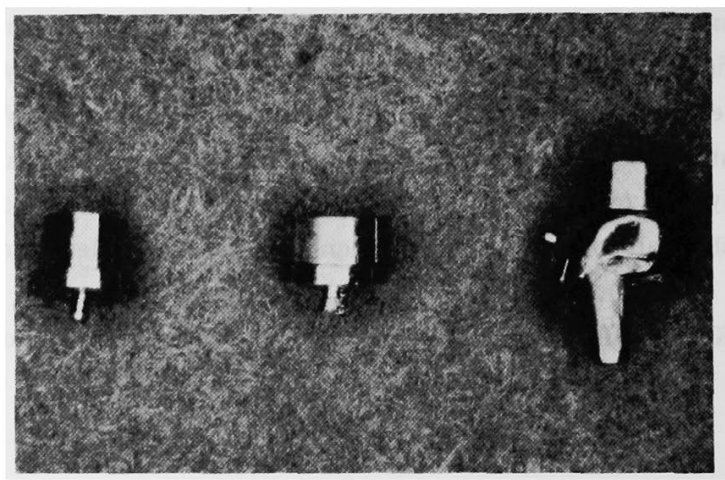

b. II 型

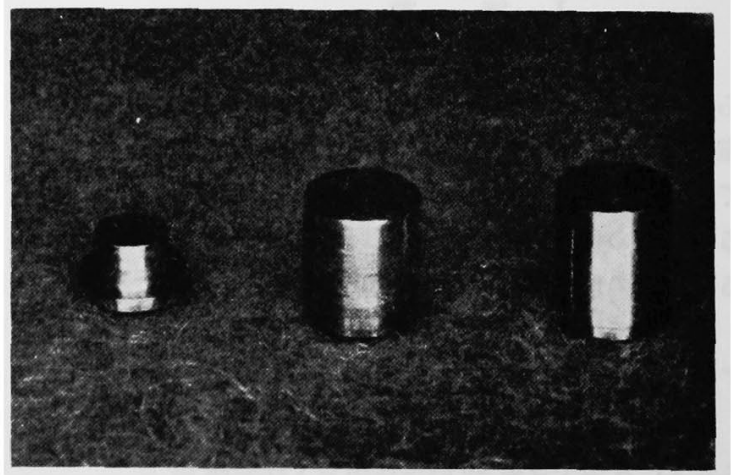

c. III型
3）磁性アタッチメントIII型（図 1-c, 図 2-c） 磁性アタッチメント I 型を既製化したもので, ステン レスあるいは磁性合金 Eで製作されている.ヨーク部 の横摇れ防止のための根面板部の空起は, 高さが 1.0 , $1.5,2.0 \mathrm{~mm}$ の 3 種類で, 軸面のテーパーは 3 度, 5 度の 2 種類があり，計 6 種類の形式がある. 使用する磁
石は $3 \phi \times 2 \mathrm{~mm}$ で, 吸引力は 250 300 $\mathrm{g}$ である. 通常 のアタッチメントと同様に, 根面板部を歯科用鋳造合金 で製作した合釘の根面板に鐵着して用いる.

なお, 磁石の口腔内に露出する面は腐触防止のため接 着性レジンや金属薄板で被覆する. この場合, ステンレ スのような磁性体の方が吸引力は増大するが，操作は煩 
雑となる.

\section{III. 臨 床 例}

磁性アタッチメント I， II，III型をそれぞれ使用した 3 症例について詳述する。

症例 166 歳男性. 昭和 55 年 3 月, 咀嚼障害および味 覚異常を主訴として来院した.

1) 口腔内所見

$\frac{4321 \mid 2356}{7321 \mid}$ が残存し, そのうち $\frac{\mid 5}{1 \mid}$ が生活歯, $\frac{1 \mid 25}{32 \mid}$ は残根状態を呈していた. 欠損部は延長ブリ ッジ65 (4)(3)と部分床義歯で補緅されていたが，上下顎 の咬合関係が不良で, 右側の延長ブリッジと下顎義歯が 強く接触するために支台歯 43 l は著しく動摇し, その歯 間部の歯周ポケットの深さは $6 \sim 7 \mathrm{~mm}$ に達して, そこ から排膿がみられた．X線写真でも岌と 3 の槽間中隔部 に著しい骨吸收が認められた（図 5-a）. 31, 71の近心部 にも 3〜4 mm 深さのポケットがあった.

なお舌側は 2 年前に腫湟のため切除されており, 舌の 感覚もやや鈍麻していた.

2）治療方針および処置

通常， $\frac{43}{3} \mid$ は抜歯の適応症とされ， $\frac{2 \mid 35}{71 \mid}$ を維持 歯とする部分床義歯が設計されるところである.しかし， 残存歯の分布状態からみると右側が主な咀嚼部位になる と考えられ，むしこれらが活用できれば義歯の安定は良 くなり，そのうえ低下した舌の機能をさらに妨げること がないように義歯の小型化が可能となる. そこで $\frac{43}{3} \mid$ の 保存を試みることにした。

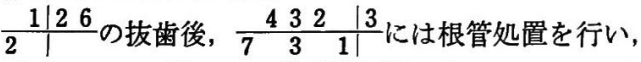
歯周ポケットに対しては外科的処置を施したのち，ブラ ッシング指導を入念に行った.

補緅処置は上顎では $32 \mid 3$ に 型の磁性アタッチメン トを，5にはコーヌステレスコープ，4 纸は根面板を設 けて, 義歯の維持安定を得る設計とした. また顎堤の状 態が良好なため，口腔感覚を障害しないように金属床の 面積をできるだけ小さくした. 下顎では7，引に I 型の 磁性アタッチメントを用い，可には根面板を設けた（図 3).

\section{3）経過観察（図 4)}

現在, 義歯装着後 6 年経過した. 5 年目に 3 のヨーク にあたる歯冠部が銭着部分の劣化により金属床から脱落 したため，接着性レジンで再装着したことと，3」の磁石 の磁力の低下により新しい磁石と交換したが, 機能的, 審美的に満足な状態が保たれている，維持歯の動摇は減

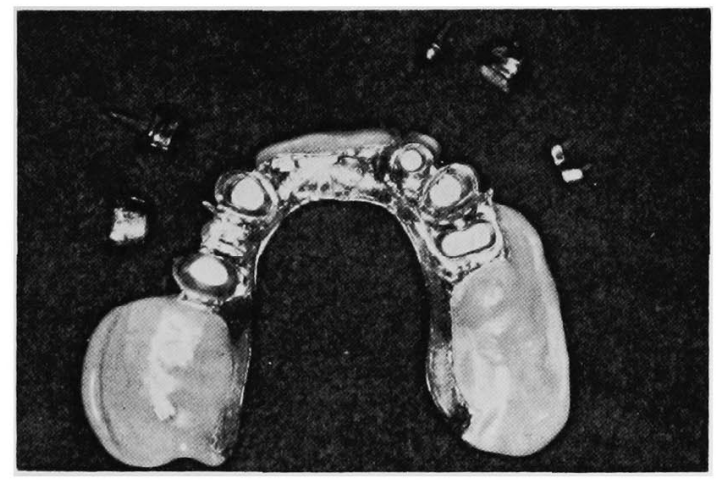

a. 上顎義歯

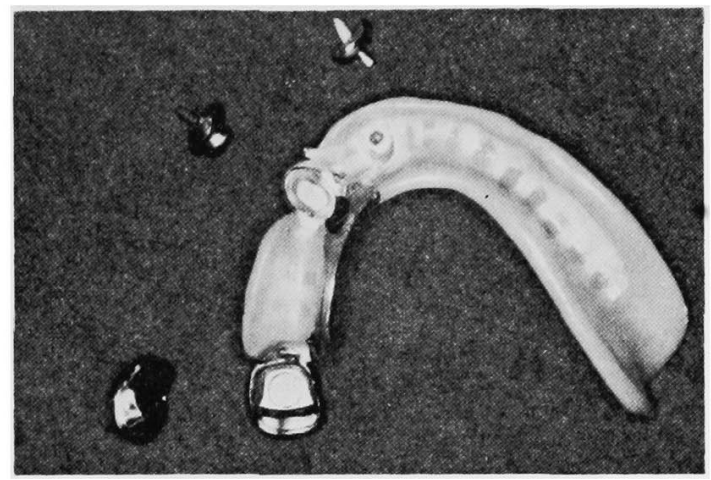

b. 下䫅義歯

図 3 上下顎完成義歯の粘膜面（症例 1)

少し, 根面板周囲の歯肉の状態も良好である，特に状態 の悪かった 43 改善は著しく, 歯周ポケットは $2 \mathrm{~mm}$ 以下に減少し， $X$ 線写真でも槽間中隔の骨の再生が確認 された (図 5-b).

症例 272 歳女性. 昭和 60 年 4 月, 3 の疼痛による 咀嚼障害を主訴として来院した。

1）口腔内所見 (図 6)

残存歯は $7 \mid 7, \overline{3 \mid 3}$ のみで， 717 は近心にレストシー トと，ガイドプレーンが形成された金属冠で，また $\overline{3 \mid 3}$ は基底結節レストシートと近遠心にガイドプレーンが形 成された陶材焼付冠で修復されており，1年 6 力月前に 装着された上顎レジン床義歯と下顎金属床義歯は，鋳造 によるレスト付き 2 腕鈎によってこれらの歯と連結され ていた，咬合状態は上下の義歯の沈下と自歯部人工歯の 摩耗によって著しく不良となり，咬合するたびに上顎前 歯部が突き上げられるような形となり，上下顎義歯はい ずれもかなりの動摇を示した. それに伴い五と厉は近 遠心方向人，引は水平，垂直の両方向に著しく動摇して いた. 3の辺縁歯肉は近心部から舌側部にかけて発赤, 腫脹し, 歯周ポケットの梁さは近心で $10 \mathrm{~mm}$, 舌側で 


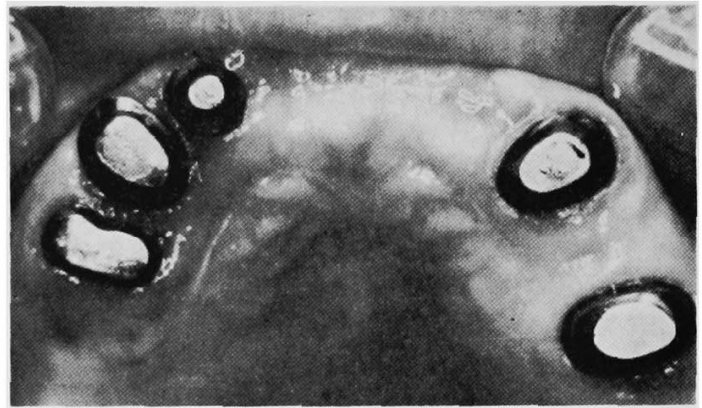

a. 上 顎

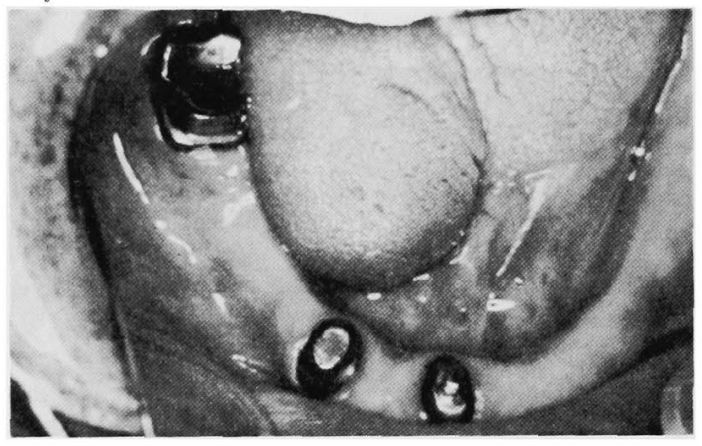

b. 下 㴿

图 46 年経過時の上下䪽の維持歯（症例 1)

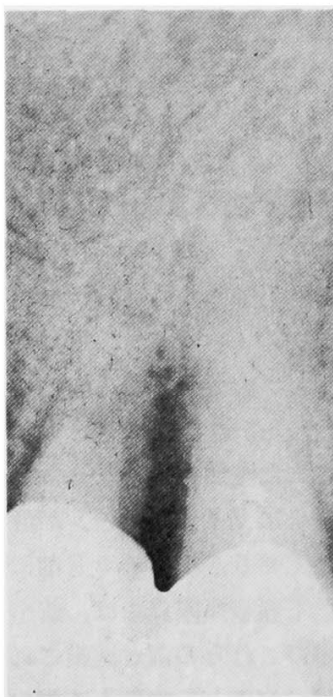

a. 初診時

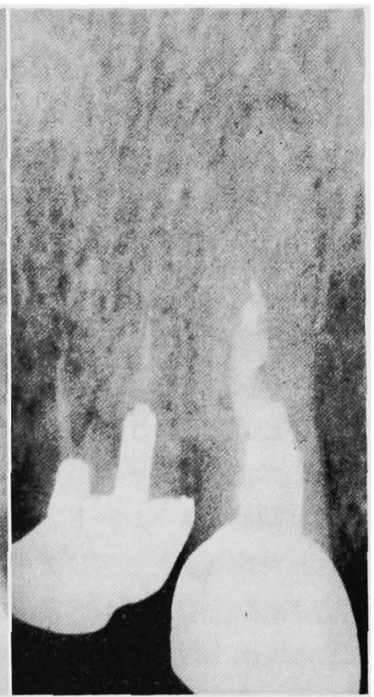

b. 4 年経過時
图 5 43 部のX線写真 (症例 1)

$8 \mathrm{~mm}$, その他の部位も 3〜 4 mm を示した. X線写真 でも3周囲の歯槽骨に著しい垂直性の骨吸収が認められ た (図 9-a).

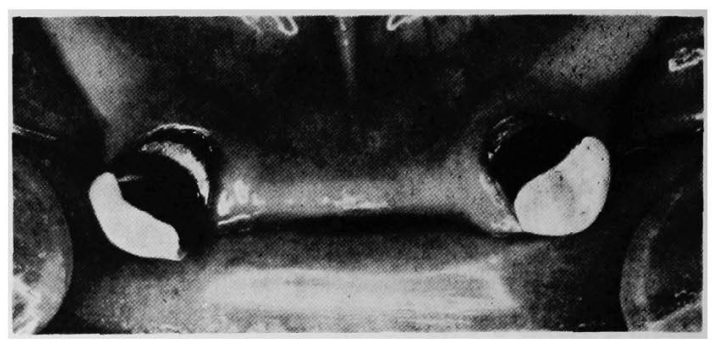

图 6 下顎残存歯 3|の歯肉辺縁の腫脹が著明（症例 2)

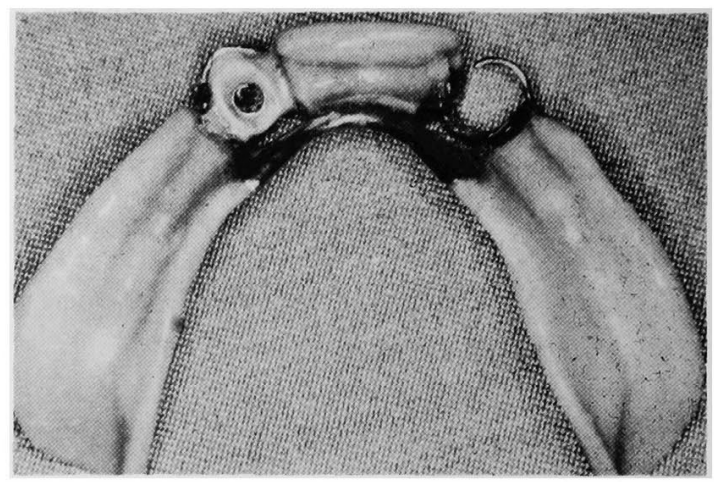

图 7 3部に磁石を装着した使用義歯粘膜面（症例 2）

2）治療方針および処置（図 7）

骨植の不良な31は抜去して, 義歯の安定と咬合の改善 を図ることも考えられるが，かえってこれまでより条件 が悪くなることは避けられない，よってろ|の保存を試み ることにした.

引の歯冠補緅物を除去した後, 盲囊搔爬とルートプレ ーニングを行い，ブラッシング指導を撤底した. そのあ と根面形成したのち, 侧方力と回転力を避けて垂直方向 の力だけを作用させるため, 根面板を磁性合金 $\mathrm{E}$ で製作 する II 型の磁性アタッチメントを使用することにした. すなわち，䫟堤に対する適合の比較的良好な使用中の下 䫑義歯の3部に人工歯を追加し, その粘膜面部に接着性 レジンを用いて II 型の磁性アタッチメントを装着した. その後臼歯部人工歯咬合面に即時重合レジンを盛り足し て, 上顎義歯との咬合のバランスを図った.

3) 経過観察 (図 8)

磁性アタッチメントの利用と白歯部に扔ける咬合関倸 の改善により, 下顎義歯の維持安定は向上した. 磁性了 タッチメント装着後 10 力月経過時に, 再び上下頻 前歯 部の接触が強くなり，上下䇗責歯の動摇が認められたの でリライニングを施し，さらに臼歯部人工歯咬合面を 修正して咬合の改善を図った. 以来 1 年 5 力月良好な経 過を示した. $\frac{7 \mid 7}{\mid 3}$ には動摇がほとんどみられず3の動摇 
む減少し，それぞれの歯肉縁の状態も極めて良好であ る. 3ではX線所見で, 周囲の歯槽骨に著しい改善が確 認された（図 9-c).

症例 353 歳女性. 昭和 58 年 3 月, 3 の動摇による咀 噯障害を主訴として来院した。

1) 口腔内所見

$\frac{3 \mid 3}{\mid 25}$ が残存し，3は生活歯，| $\frac{3}{25}$ は無髄歯で根 管処置が施され，欠損部は可34(5)のブリッジと部分床 義崡で補緅されていた. 咬合状態をみると厓345のブ リッジが 3 と強く接触するため，级著しく動摇し, 全 周にわたり深さ約 $3 \mathrm{~mm}$ の歯周ポケットが認められ， $\mathrm{X}$ 線写真では根尖部に大きな透過像が見られた（図 12-a). また他の残存歯の骨植状態は $3 \mid$ が良好, 5 がやや不良，

2功不良であった。

2）治療方針および処置（図 10）

$\mid \frac{3}{2}$ は保存不可能とみられたが，これらを抜去すると $\frac{3 \mid}{15}$ のみ残存してすれ違いの状態になり, 義歯の安定は

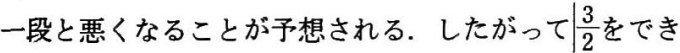
るだけ保存したほうが良いと判断した。

送と 5 の歯周ポケットは外科的処置により改善し, ブ ラッシング指導を十分行った.

補緅装置は，上顎ではにに而型の磁性アタッチメント で突起のテーパー 3 度, 高さ $1.5 \mathrm{~mm}$ のものを用い，3 には義歯の動摇を抑える目的でューヌステレスコープを

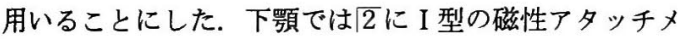
ント，可には型の磁性アタッチメントで突起のテーパ -3 度, 高さ $1.0 \mathrm{~mm}$ のものを用いた. $\frac{3}{5}$ の根面板と
歯冠部およびコーヌステレスコープは白金加金で製作し た. また上下顎の金属床は維持歯の煩側と舌側を開放し た形態にした.

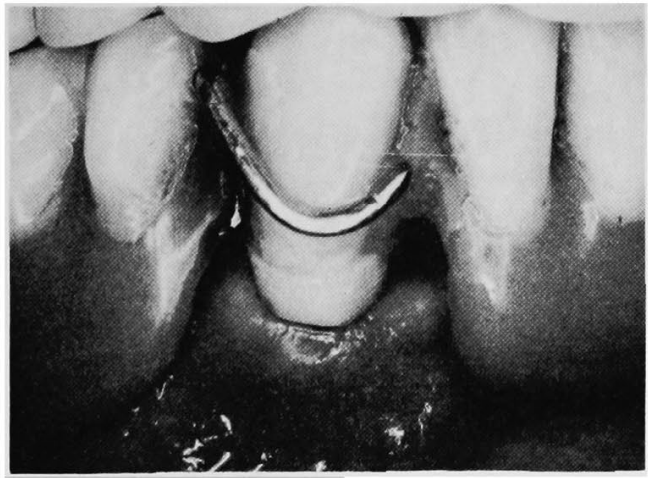

a . 根面板周囲の歯肉の状態は良好

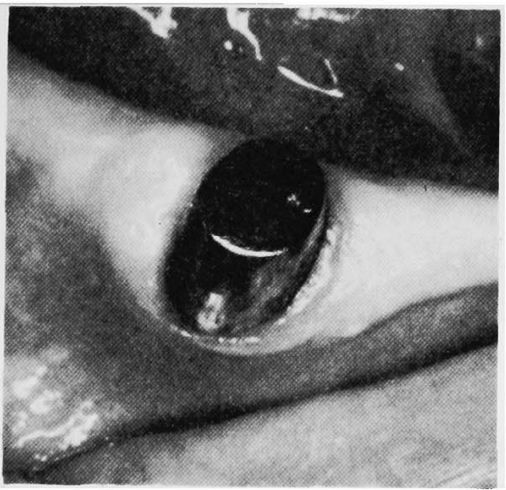

b. $\overline{3 \mid}$ の根面板

図 81 年 3 カ月経過時の $\overline{3}$ 部

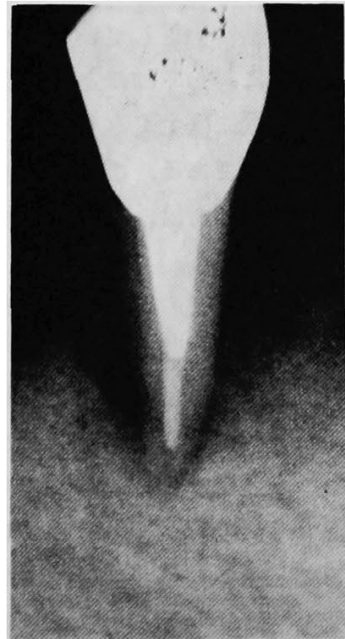

a . 初診時

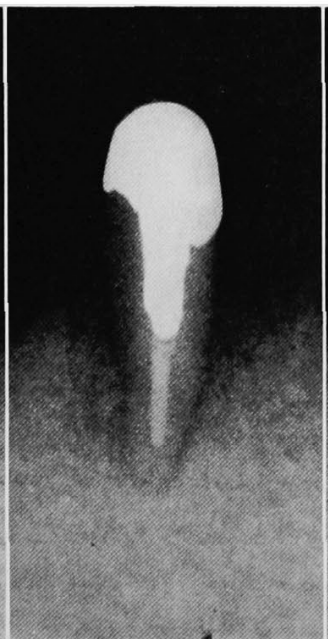

b. 3 力月経過時

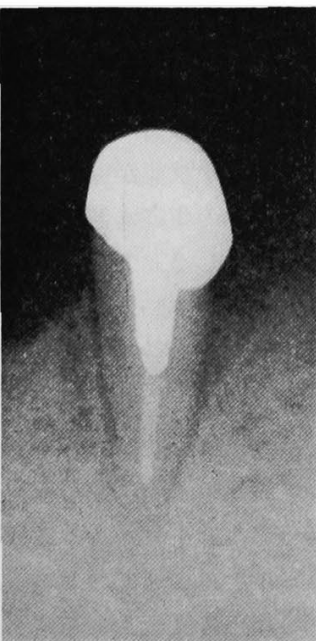

c. 1.5 年経過時

图 9 可部のX線写真（症例 2) 


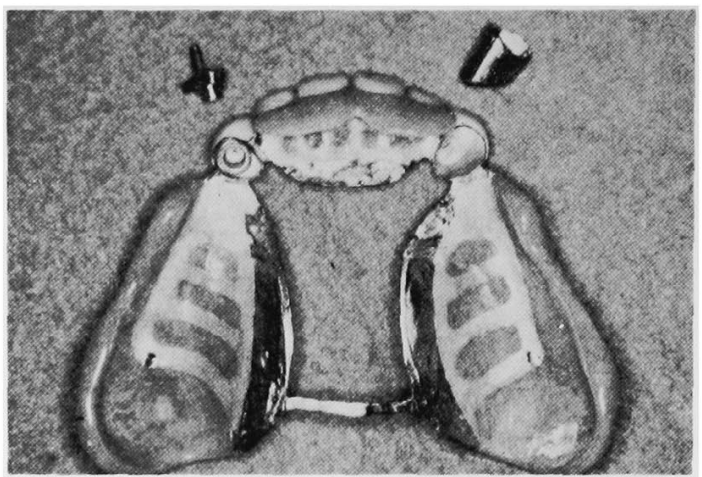

a . 上顎義歯

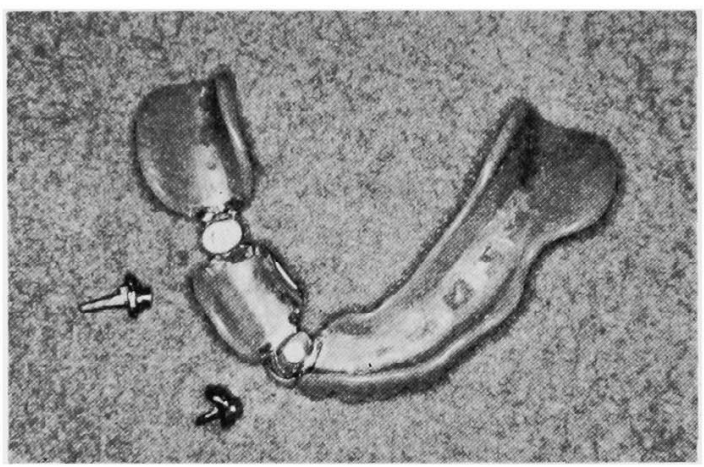

b . 下顎義歯

図 10 上下颚完成義歯粘膜（症例 3 )

\section{3）経過観察（図 11）}

義歯装着後 4 力月目に, 下顎義歯の動摇があるためり ライニングを行った. 2 年目に上顁義歯が脱落し易くな ったとのことで来院した，尚のコーヌステレスコープは 維持力がほとんどないようにしたため，迆の磁力が低下 寸ると脱落し易くなる． 级の磁石を交換することにより 彖の維持力は回復し, 義歯の維持, 安定は元にもどり, 2 年 6 力月経過時まで良好な状態が保たれていた. 維持 歯の動摇度は減少し, 周囲の歯肉も健康で, なかでも!3 の歯周組織の回復がめざましく, X線写真でも歯槽骨の 著しい改善が確認された（図 12-c).

\section{IV. 考察}

雪周治療学の著しい進歩により, 従来抜歯の適応症と された歯でも, プラークコントロールの撤底によって保 存可能となることが明らかにされてきている. また歯科 インプラントに対する関心の高まりとあいまって, でき るだけ歯を残そうとする傾向が強まっている. しかし， 補緅物の設計にあたっては現在のところ深い歯周ポケッ
31 巻 6 号 (1987)

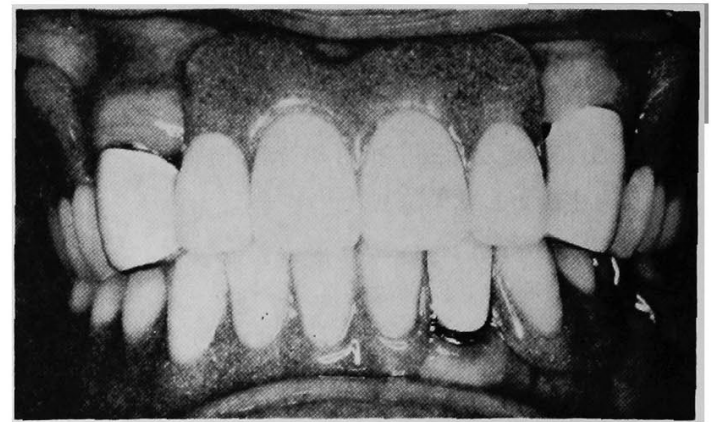

a 、咬合状態

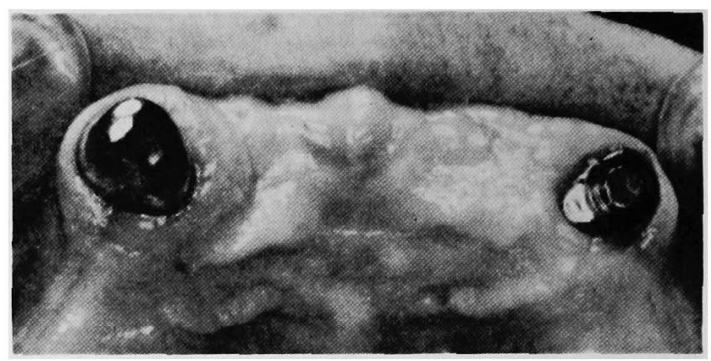

b. 上顎の維持歯

図 112 年 6 力月経過時の口腔内状態 (症例 3)

トを有する歯や著しい動摇のある歯などは，前処置の段 階で抜歯されるのが通例である，著者らはこれまで検討 してきた磁性アタッチメントが，このような歯に対して も効果的に使えるのではないかとの考えから試用し，か なり優れた成果を得ることができた.

\section{1. 磁性アタッチメントの特性（図 13, 14）}

ここで使用した磁性アタッチメントは中に内藏された 磁石の吸引力を維持力としているので, その構造によっ ては側方的な力に対してはほとんど抵抗性がない.この 点は他の維持装置には全くみられない特徴で，維持面に とって大きな利点である.これに関連して磁性アタッチ メントを用いた義歯では，2，3の好ましい性質をあげ ることができる.

第 1 点は義歯の着脱の容易さである．義歯を装着しよ うとするとき, 義歯を装着部位に近つけると磁石の吸引 力により所定の位㯰に自然に収まり易い.また磁石の吸 引力は䧺開の程度に応じて急減することから，義歯をは ずそうとするときには初めに瞬間的に磁石の吸引力に抗 するだけの 200〜400 g の弱い力を加えればよく，その 際クラスプなど他の維持装置を用いた義歯の場合にみら れるような維持歯に対する大きな毫引力や前方力は一切 加わらない.

第 2 点として, 維持力は磁石と磁性合金との平面間の 


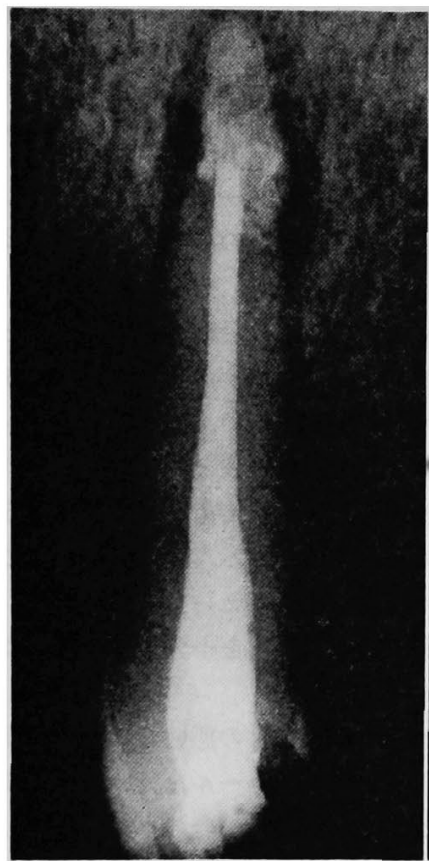

a. 初診時

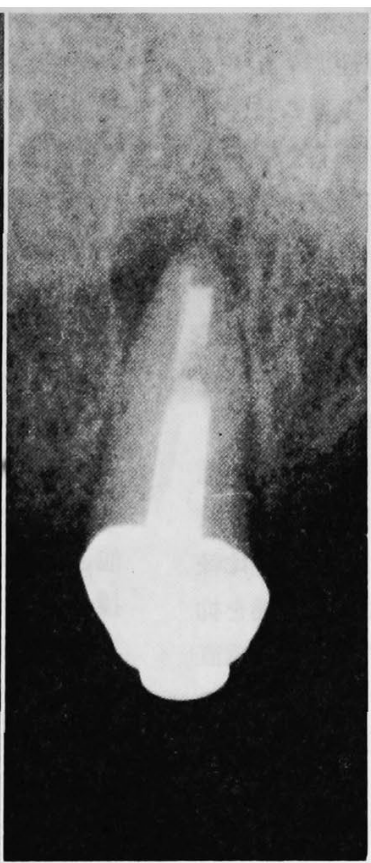

b. 2 年経過時

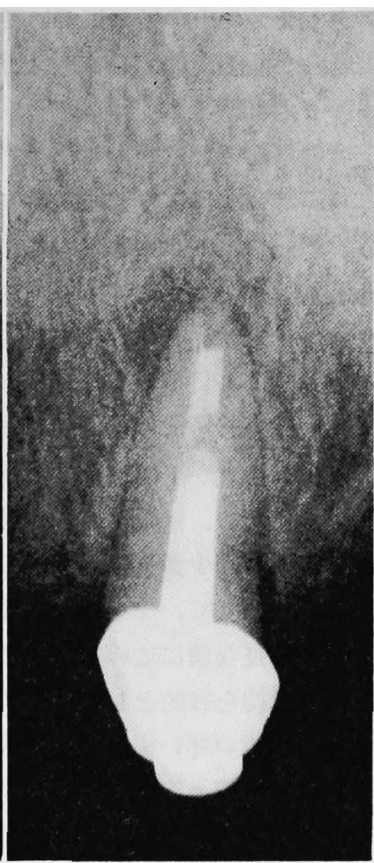

c. 2.5 年経過時

図 $12 \leq 3$ 部X線写真 (症例 3)

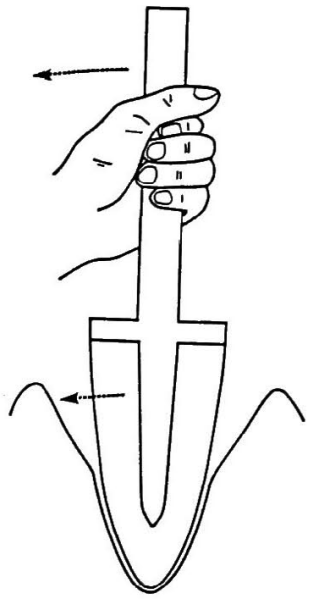

a . 他の維持装置

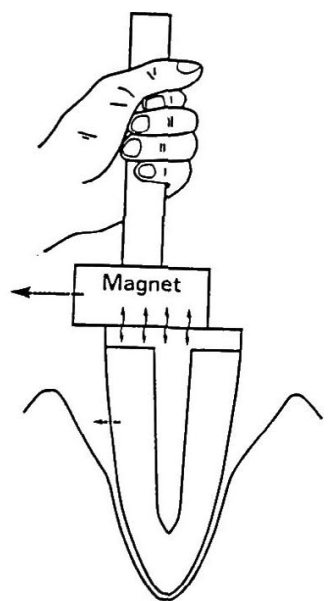

b．磁性アタッチメント

图 13 側方力に対する磁性アタッチメントの作用

吸引によって生じ, 水平方向の力は垂直方向の約 $1 / 3,70$ 〜90 g であることから, 磁性アタッチメントを用いた義 歯では機能時の床の浮き上がりを防止するような垂直方 向の維持力を保持しながらも, 歯根にとって有害な回転 力や側方力はほとんど除くことができる.

第 3 点は, 義歯の維持力はすべて磁石の吸引力に頼る ため義歯の着脱方向には関倸せず，したがって指向性の

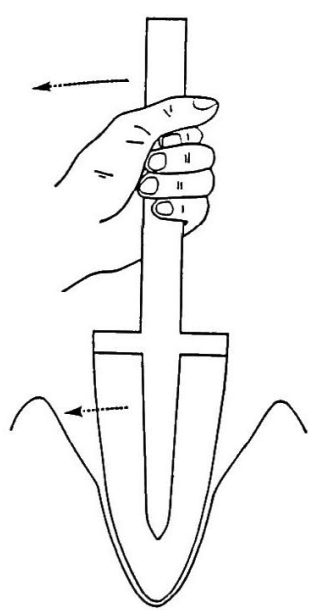

a . 他の維持装置

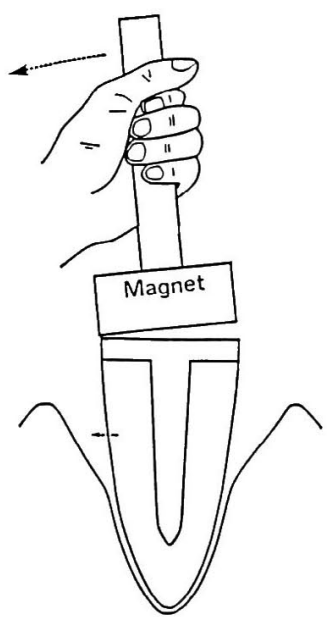

b. 磁性アタッチメント
図 14 回転力に対する磁性アタッチメントの作用

強い他の維持装置との併用や, 全部床義歯タイプのオー バーデンチャーの場合に上顎結節部や前歯部の䫟堤にア ンダーカットがあるときにも，辺縁封鎖を破ることなく 残存歯に維持を求めることが可能である.

以上のごとく磁性アタッチメントは, 他の維持装置に みられない臨床的に有利と考えられる特性を持ってい る. 
$126-1452$

補繁誌

\section{2. 磁性アタッチメントの種類について}

これまで著者らが臨床で使用してきた磁性アタッチメ ントには，I， II， III型の 3 種類がある．Ｉ型の磁性ア タッチメントでは根面板部を製作した後, 磁石を挿入す るヨークをこれに適合するように鋳造により製作する. この技工操作は煩雑で，しかも鋳造した接合面を研磨し て十分密着させることがきわめて困難なため磁気回路が 不完全になり易く，期待通りの吸引力が得にくい欠点が ある.これに対し，II，III型の磁性アタッチメントは技 工操作が容易で, 臨床的に簡便に使用できる.

【型の磁性アタッチメントは根面部と磁石とが平面同 士で接触する形態のため, 前述の 3 つの性質をすべて兼 備している. そのため, 少数歯残存症例でも骨植の比較 的良好な歯を維持歯として，できるだけ義歯の動摇を抑 えたうえで骨植の不良な歯にこのアタッチメントを垂值 方向の作用として維持を目的として使用すれば，抜歯の 対象となるような状態の悪い場合でも, 維持歯として十 分活用でき，義歯の維持，安定にとって有効である.こ とに義歯の維持, 安定の鍵となる歯が骨植不良な場合に, このアタッチメントが使用できることは大きな意義があ る. つまり,この II 型の磁性アタッチメントは側方力に 対して抵抗できないので，副維持装置的に用いられて効 果がある. これに対し, 而型の磁性アタッチメントはメ 一ル部に突起が付与され, 側方力や回転力に抵抗する形 態となっている. 他の維持装置と同様な把持要素が形態 的に付与されているので, 維持力として少々弱いながら 主維持装置として使用可能である. 磁性アタッチメント としての着脱時に無理な力が加わらないという第 1 の特 性は残るものの, 第 2 , 第 3 の特性は失われる. そのた めII型の磁性アタッチメントは， 【型のものを使用する 場合よりもやや条件の良い歯を対象として，使用するの がよいと考えられる.

\section{3. 臨床例の経過観察から}

1）磁性アタッチメントについて

磁性アタッチメントの吸引力の低下が症例 1 の 3 で 5 年経過時に, 症例 3 の 3 で 2 年経過時に認められた. ま た長期間経過するうちに，磁力はまだ十分あるものの磁 石の表面が錆る傾向がみられた。 これらは磁石を接着性 レジンでシールしたものである．接着性レジンの封鎖性 は実験的に確認されているが, 強い咬合力や力が反復し て加わる部分での使用, 口腔内の急激な温度変化, レジ ン自体の吸水性などを考虑すると，接着性レジンだけで シールするのは，長期間にわたって使用する磁性アタッ
31 巻 6 号 (1987)

チメントにとってやや問題があると考えられる. そのた め現在, 磁石のシールについて他の方法を検 討中であ り，近いうちに解決されると思われる.

2）維持歯にした骨植不良歯について

3つの症例の磁性アタッチメントを応用した骨植不良 歯は, 症例 1 では 4 」と 3 」槽間中隔部の骨吸収, 症例 2 の3では垂直性の骨吸収, 症例 3 の〔3 では根尖部の骨吸 収と，いずれも前処置の段階で抜去されると一般に考え

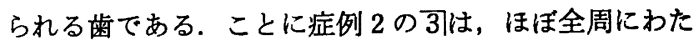
って垂直性の骨欠損を伴い，歯周ポケットも 6〜10 mm を示しており，外科的処置を施しても保存することは困 難と思われるもので, 維持歯として利用することは不可 能と考えられるものである. しかし一方，これらの歯を 抜去すれば，いずれもかえって義歯の維持，安定を得る ことは困難となり, 義歯を十分機能させるにはきわめて 不利になるはずである.

ここでは, これれら条件の悪い歯に適切な歯周処置と徹 底したプラークコントロールを行い, 維持装置に磁性ア タッチメントを応用して咬合の平衡を回復した結果, 義 歯の維持, 安定は向上し, 同時に維持歯の歯周組織にも 著明な改善がみられた. つまり, 辺縁歯肉の健康の回復 と歯の動摇の減少はもちろん, X線写真より歯槽骨の再 生さえ認められた.

すなわち, 磁性アタッチメントの使用は, 従来抜去さ れるはずの骨植不良な歯が維持歯として使用可能となる ため，義歯を設計する場合の幅が広がり，またすれ違い 咬合などいわゆる難症例や無歯䫅症例の回避につながる ばかりでなく，歯根の保存により顎堤の形態保持にも役 立ち, 補緅の臨床上きわめて有意義であるといえる.

\section{V. 結 論}

磁石を利用した 3 種の磁性アタッチメントとその骨植 不良歯への応用について述べた。 これらのアタッチメン 卜を適切に使用すれば, 従来保存が困難とされた骨植不 良歯でも維持歯として十分活用でき, 義歯の維持安定に とってきわめて有効であることが明らかにされた.

\section{文献}

1）水谷 紿, 石幡伸雄, 藍 稔：磁性合金の補棳領域にお ける応用, 第 1 報, 実用的精度, 補緅誌, $25: 687 \sim 694$, 1981.

2）石幡伸雄，水谷 紿，藍 稳：磁性合金の補級領域に打 
ける応用，第 2 報，根面維持装置に応用するための基礎的 研究, 補緅誌, $26: 993 \sim 998,1982$.

3）石幡伸雄, 水谷 紘, 藍 稔：磁性合金の補経領域にお ける応用, 第 3 報, 磁性アタッチメントに関する基磷的研
究, 補経誌, $27: 937 \sim 942,1983$.

4）石幡伸雄, 水谷 紘, 藍稳: 磁性合金の補緅領域にお ける応用, 第 4 報, 磁性アタッチメントの臨床応用例, 補 緅誌, $28: 515 \sim 521,1984$. 